\title{
Towards An Evolutionary Psychological Categorization of Individual Differences
}

\author{
Jan Guus Waldorp* and Harry van de Wiel \\ University of Groningen, University Medical Center, Europe
}

Submission: April 07, 2017; Published: April 28, 2017

*Corresponding author: Jan Guus Waldorp, Wenckebach Institute, University of Groningen, University Medical Center, Groningen, The Netherlands, Europe, Email: waldorp@mindlogyx.com

\begin{abstract}
According to evolutionary theory, individual differencesare essential for a sexual reproducing species such as humans. Based on our research of evolutionary psychological literature we propose that, in order to successfully attain inclusive fitness, the individual must be successful in at least one of the fundamental evolved adaptations. The three evolved fundamental adaptations comprise a) successfully forming and maintaining a meaningful romantic relationship, b) successfully cooperate with members of a social group and c) competing successfully with rivals for prestige. To deal with these three challenges the human mind contains three different mechanisms following different neural paths and use different memory systems, one of which will eventually lead to a specific motivational profile that guides a social strategy of the individual. Inherited genes interacting with the environment and prenatal and postnatal experiences motivate the individual already at an early age to 'prioritize' one of the three adaptations that proves to be the most successful social 'niche'. This motivated behavior stays with the individual and remains relatively stable over lifetime. It is responsible for decision-making and guiding the individual's social strategy for approaching and influencing the behavior of others. We propose to categorize these three adaptations into a model that serves to distinguish between three different approaches of individual differences and decision making. Risk assessment, being another important aspect of human behavior, has been integrated in this novel framework.
\end{abstract}

Keywords: Sexual Selection; Individual Differences; Categorization; Evolved Adaptations; Life History; Evolutionary Psychology; Motivation; Risk Assessment

\section{Sexual Selection, Mate Choice and Reliable Signals}

Sexual selection is essential for natural selection. Sexual selection implies the option to choose between different individuals. Recognizing that females invest more in their offspring than males, the quintessential question in sexual selection is: how can women be sure they choose the right male that will provide quality genes and resources for her and for her offspring? When Darwin published his book The descent of man and selection in relation to sex [1], in dealing with the problem of sexual selection he was somewhat baffled by the female preference for some males above others. Although he clearly understood that females have preferences for certain males, he never satisfactorily explained why such preferences evolve [2]. Much to his chagrin, Darwin was unable to solve the puzzle of the ostentatious tail of the peacock, the brilliant colors and song display of some birds and the aesthetic attraction of females for these phenomenal ornamentations in particular.

Failing to see the survival advantages of such elaborate ornamentation, he shared his frustration in a letter to his friend
Asa Gray [3] writing "The sight of a feather in a peacock's tail, whenever I gaze at it, makes me sick!" The problem persisted until some models appeared that seemed to solve Darwin's dilemma, starting with Fisher's runaway sexual selection model [4] outlining a genetic mechanism for the joint evolution of female preferences and secondary male ornamentations. "Inevitably there is a kind of evolutionary battle of the sexes," George Williams [5] wrote, showing males to be natural born salesmen and females as reluctant consumers. Then, in 1975, an article appeared entitled Mate selection - a selection for a handicap [6,7]. In the article biologist Amotz Zahavi suggests that a reliable secondary sexual ornamentation can only be signaled by a male that can afford to lower his chance of survival. This makes a signal a handicap that can only be advertised by males of high quality. In fact, Zahavi argued, the handicap is a genetic quality test imposed in which both males and females lose. Males lose in time, energy and added risk in advertising, while females may lose bearing less fit sons to stand the pressures of selection. 
However, although Darwin [1] assumed that women choose and men compete, it became apparent that human males and females under near-monogamous social relationships practice mutual mate choice [8]. Both sexes select for the specific physical and mental mate qualities to produce successful and healthy offspring. Buss and Barnes [9] demonstrated that differences in mate preferences between human males and females diminish under monogamy: 7 out of 10 preferences were similar for both sexes. Mutual mate choice suggests that both sexes have to fend off rivals, as was found to be the case: females can be just as fierce competitors as males [8,10-13] and can be equally socially dominant [14].

\section{The Development of Individual Differences}

Mate choice and reliable signals are relevant because humans do not select mates at random. Individuals deploy social strategies that are guided by their motivational profile to select mates that have a potential for reproductive success. For an individual to develop a motivational profile we suggest that there are two fundamental causes. Firstly, there are three fundamental adaptations that are essential to get access to resources and mates to attain inclusive fitness: a) building and maintaining meaningful romantic relationships, b) being accepted and forging cooperative relationships with members of a social network and c) competing successfully with rivals for mates, resources and social prestige $[7,15,16]$. We postulate that the mind of the individual is calibrated by events from the prenatal period onwards towards a favorable competitive strategy that 'prioritizes' one of the three evolved adaptations over the others. The adaptations follow separate trajectories from each other in the brain for categorizing, emotion, learning and memorizing.

A process called cascading constraints progressively limit new connections in the brain, alternative pathways which means that there are less and less behavioral possibilities left [17]. As the self-organizing systems operate independently, an individual may be successful in one domain but less successful or fail in one or both of the two remaining domains [16]. Based on its early experiences conjointly with his inherited genes, the mind of the individual will 'prioritize' one of the three fundamental adaptations. This prioritized adaptation will stay with him creating a motivational profile that guides his social strategy and which is relatively enduring over time. Individual differences are responsive to the input from the ecological and social environment that interacts with the individual's genes. This conjoined force influences whether an individual is biased towards a fast or a slow, a 'risk prone' or a 'risk aversive', reproductive tradeoff strategy $[14,18]$.

Typically the human brain seizes up a situation, predicts possible outcomes of different actions and chooses a specific action [19]. This strategy develops from the prenatal period of the individual onwards through the interaction between the inherited genes and the social environment. Thus, the action is (also) dependent on his 'fast' or 'slow' reproductive strategy. Thus, together with the prioritized adaptation it will direct its social strategy to navigate the social world of the individual. As people plan their future actions through mental time travel [20] and anticipate possible (social) obstacles, the prioritized adaptation combined with their fast or slow reproductive strategy will guide a social strategy that is directed at amassing resources and mates.

\section{Genetic Inheritance}

Behavioral genetics have attributed much to our understanding of the development of individual differences. Genes may account for influencing up to $50 \%$ of human behavior and the stability of individual differences from age to age. Genes are found to be responsible for political beliefs, religiosity, altruism, food preferences and general intelligence [21]. Children and adults also select, modify and create environments that correlate with their genetic propensities [21] that we propose as the evolved adaptations. Thus, individuals create a specific niche for the socialization processes with their peers, typically from around 3-4 years of age onwards.

Juveniles quickly discover that they are successful in one adaptation but less in the other two. By pure necessity, however, individuals have to function, be it less successful, in one or both of the two other adaptations. They will, however, not be able to excel equally in all three domains. As the quality of their behavior depends for some $50 \%$ on their inherited genes, during their lifetime they will not be able to switch from one adaptation to another.

\section{Categorizing Individual Differences and Decision Making}

Females obviously differ biologically and mentally from males. These differences are also expressed in their social strategy: in general women are more sociable than men. They place more emphasis on personal relationships whereas men are more inclined to participate in group activities. In general females respond empathically and intimately more than males. They are better in theory of mind or 'mindreading' [22]. They are better in reading facial expressions, value relationships higher and are more altruistic and reciprocal, have a better command of language and have less problems talking about emotions, have a more empathic parenting style and strive for long term relationships [13]. The so called 'female brain' is the innate drive to understand, predict and relate to the behavior of others. In the extreme it is the urge to help others if they are in distress or asking for help. Males in general take a greater interest in their personal status than females, struggle for power, politics and competition, are more aggressive and dominant. Males are, again in general, better at systemizing and pattern recognition. Because they have also a greater attention to detail than women, 
they are better in - and more attracted to - mathematics, physics and engineering.

\section{Towards a Categorization of Individual Differences}

We have categorized the female and male characteristics in an evolutionary psychological framework. We have structured the framework according to the evolved adaptations of the three evolved fundamental adaptations comprising a) successfully forming and maintaining a meaningful romantic relationship, b) successfully cooperate with members of a social group and c) competing successfully with rivals for prestige. We have labeled these 'empathic' (top level), 'coalitional' and 'hierarchal' respectively. These descriptions are rather arbitrarily but we wanted to 'catch' the specific characteristics of each in one word. We have added a risk prone and risk aversive assessment [23] because this characteristic plays a major role in decision making.

This framework specifies the individual differences, with suggestions of fitness boundaries imposed by one of each of the 'preferred' evolved adaptations. We have designed this framework based on our own research and have combined it with the Revised Empathizing-Systemizing System of BaronCohen [22].

\section{Discussion}

Based on available research this article has explored an evolutionary approach to develop a framework to categorize individual differences. We propose that individual differences are contingent on the three evolved adaptations that are designed by evolution to promote the individual's success in inclusive fitness. We have proposed that one of the three adaptations that best matches an individual's early experiences combined with his genetic inheritance, one of the three evolved adaptations is nonconsciously prioritized. Using this as a starting point we have designed a psychological framework that creates an opportunity to categorize the motivational profile of the individual. We have added the risk prone and risk aversive elements of life history and the Empathizing-Systemizing system [22]. Thus the framework can be used as a novel feature for understanding, predicting and segmenting individual behavior of female and male behavior to support practical applications in, for example, human resources, education, consumer behavior, branding and in fact for all practical aspects of human behavior.

\section{References}

1. Darwin C (1871) The descent of man and selection in relation to sex.

2. Jones AG, Ratterman L (2009) Mate choice and sexual selection: What have we learned since Darwin? PNAS 106: 1.
3. Darwin C (1860) Letter to Asa Gray.

4. Fisher RA (1915) The evolution of sexual preference. Eugen Rev 7(3): 184-192.

5. Williams GC (1966) Adaptation and natural selection: A Critique of Some Current Evolutionary Thought, Princeton University Press, USA.

6. Zahavi A (1975) Mate Selection-A Selection for a Handicap.J Theor Biol 53(1): 205-214

7. Zahavi A (2003) Indirect selection and individual selection in sociobiology: my personal views on theories of social behavior. Animal behavior 65: 859-863.

8. Hooper PL, Miller GF (2008) Mutual Mate Choice Can Drive Costly Signaling Even Under Perfect Monogamy. International Society for Adaptive Behavior 16(1): 53-70.

9. Buss DM, Barnes M (1986) Preferences in Human Mate Selection. Journal of Personality and Social Psychology 50(3): 559-570.

10. Campbell A (2013) Mutual Mate Choice: Sexual Selection Versus Sexual Conflict. Psychological Inquiry 24(3): 178-182.

11. Hrdy Sahrah Blaffer (2009) Mothers and others, The Evolutionary Origins of Mutual Understanding, Belknap Press, USA.

12. Miller GF (1998) How mate choice shaped human nature. Lawrence Erlbaum.

13. Miller GF (2000) The mating mind. Vintage, London.

14. Hawley P, Little TD, Card NA (2008) The myth of the alpha male: A new look at dominance-related beliefs and behaviors among adolescent males and females. International Journal of Behavioral Development 32: 76.

15. Buss DM (1991) Evolutionary personality psychology. Annual Review of Psychology 42: 459-491.

16. Harris Rich J (2011) Explaining individual differences in personality: why we need a modular theory, Oxford University Press, India.

17. Lewis MD (2005) Self-organizing individual differences in brain development. Developmental review 25: 252-277.

18. Chisholm JS (1999) Attachment and time preference: relations between early stress and sexual behavior in a sample of American university women. Hum Nat 10(1): 51-83.

19. Prokosh MD, Coss RG, Scheib JE, Blozis SA (2009) Intelligence and mate choice: intelligent men are always appealing. Evolution and Human Behavior 30(1): 11-20.

20.Suddendorf T, Corballis MC (1997) Mental Time Travel and the Evolution of the Human Mind. Genet Soc Gen Psychol Monogr 123(2): 133-167.

21. Plomin R, DeFries JC, Knopik VS, Neiderhiser JM (2016) Top 10 Replicated Findings From Behavioral Genetics. Perspect on Psychol Sci 11(1): 3-23.

22. Baron-Cohen S (2005) The Empathizing System: a revision of the 1994 model of the Mindreading System. Origins of the Social Mind, Guilford Publications Inc, USA.

23. Blanchard DC, Blanchard RJ (1988) Ethoexperimental approaches to the biology of emotion. Annu Rev Psychiol39: 43-68. 


\begin{tabular}{|l|}
\hline \multicolumn{1}{|c|}{ Your next submission with Juniper Publishers } \\
will reach you the below assets \\
- Quality Editorial service \\
- Swift Peer Review \\
- Reprints availability \\
- E-prints Service \\
- Manuscript Podcast for convenient understanding \\
- Global attainment for your research \\
- Manuscript accessibility in different formats \\
( Pdf, E-pub, Full Text, Audio) \\
- Unceasing customer service \\
Track the below URL for one-step submission \\
https://juniperpublishers.com/online-submission.php \\
\hline
\end{tabular}

